\title{
Aflibercept and Ranibizumab Modulate Retinal Pigment Epithelial Cells Function by Acting on Their Cross Talk with Vascular Endothelial Cells
}

\author{
Stefano De Cillàa Serena Farruggio ${ }^{b, c} \quad$ Grazia Cocomazzi ${ }^{b, c}$ David Mary ${ }^{b, c}$ \\ Micol Alkabes ${ }^{a} \quad$ Luca Rossettid $^{d}$ Stela Vujosevic ${ }^{a}$ Elena Grossini ${ }^{a, c}$ \\ aphthalmology Unit, Department of Health Sciences, University East Piedmont, Azienda Ospedaliera \\ Universitaria Maggiore della Carità, Novara, Italy, 'Laboratory of Physiology and Experimental Surgery, \\ Department of Translational Medicine, University East Piedmont, Novara, Italy, 'AGING Project, \\ Department of Translational Medicine, University of Eastern Piedmont, Novara, Italy, dEye Clinic, San \\ Paolo Hospital, University of Milan, Milan, Italy
}

\section{Key Words}

Anti-VEGF $•$ Cell viability $\bullet$ Cross-talk $・$ Mitochondrial function

\begin{abstract}
Background/Aims: We performed co-culture experiments between human RPE cells (ARPE19) and human umbilical vascular endothelial cells (HUVEC) in order to evaluate how antiVEGF drugs could affect NO release, mitochondrial function, the oxidative status, proliferation and migration of RPE cells through modulation of their cross talk with vascular endothelial cells. Methods: The co-culture HUVEC/RPE, was exposed to Ranibizumab/Aflibercept in the absence/presence of the NO synthase (NOS) inhibitor, the phosphatidylinositol 3'-kinase (PI3K), the extracellular-signal-regulated kinases $1 / 2$ (ERK1/2) and the p38 mitogen-activated protein kinase (p38 MAPK) blockers. Specific kits were used for cell viability, mitochondrial membrane potential, NO, ROS and GSH production. Western blot was performed for apoptosis markers, NOS isoforms, and others kinases detection. Cell migration was analyzed by scratch assay, whereas cell proliferation and cell cycle through xCELLigence and flow cytometry. Results: In RPE cells co-cultured with HUVEC in physiological conditions, Aflibercept/Ranibizumab increased $\mathrm{NO}$ release in a dose and time-dependent way. Opposite results were obtained in peroxidative conditions. Both anti-VEGF agents were able to prevent the fall of cell viability and mitochondrial membrane potential, an effect which was reduced by various inhibitors, and increased cell migration. Aflibercept/Ranibizumab counteracted the changes of apoptosis markers, NOS expression/activation, PI3K and ERK1/2 activation caused by peroxidation.
\end{abstract}




\section{Cellular Physiology Cell Physiol Biochem 2020;54:161-179 \\ \begin{tabular}{ll|l} 
and Biochemistry & $\begin{array}{l}\text { DOl: 10.33594/000000212 } \\
\text { Published online: } 12 \text { February } 2020\end{array}$ & $\begin{array}{l}\text { O } 2020 \text { The Author(s). Published by } \\
\text { Cell Physiol Biochem Press GmbH\&Co. KG }\end{array}$ \\
\cline { 2 - 3 } &
\end{tabular} \\ De Cillà et al.: Anti Vascular Endothelial Growth Factors and Retinal Function}

These results were confirmed by cell cycle analysis. Conclusion: This study has shown new mechanisms at the basis of protective effects elicited by Aflibercept/Ranibizumab in RPE cells. HUVEC stimulated with Aflibercept/Ranibizumab, could release some paracrine factors that can modulate the RPE cells response in both physiologic and peroxidative conditions.

(C) 2020 The Author(s). Published by Cell Physiol Biochem Press GmbH\&Co. KG

\section{Introduction}

The age-related macular degeneration (AMD), is a complex chronic neurodegenerative disease and is the major cause of blindness among old people [1-3]. Although the precise etiopathogenesis of AMD is still unknown, it has been postulated that the reduced choroidal blood flow would result in changes in the retinal pigment epithelial (RPE) function with accumulation of lipoproteins that ultimately lead to RPE cell degeneration and altered permeability of the Bruch's membrane [4-7].

There is strong evidence suggesting that oxidative stress has a major role in the development and progression of AMD. The retina and RPE are extremely susceptible to oxidative stress damage: they both have high metabolic demands and require large amounts of adenosine triphosphate to support their functions [8]. Due to its high metabolic activity, RPE cells are enriched with mitochondria, which act as major source of ROS in RPE cells. Increased mitochondrial damage and generation of ROS are associated with AMD, suggesting that damaged mitochondria and other oxidatively modified components are not efficiently removed by the aged- RPE cells [9].

Although nitric oxide (NO) could play an important role at the onset of AMD by its action on the vascular tone and ocular blood flow, there has been only a few studies to characterize the nitric oxide synthase (NOS) isoforms in the choroid [10-15]. In this context, small amount of eNOS-derived NO could act as a potent vasodilator and play a key role in the physiological regulation of ocular blood flow $[10,16,17]$. Furthermore, in RPE cells, NO would contribute to the function of phagocytosis of rod outer segments and regulation of vascular endothelial growth factor gene expression. Under oxidative stress however, a high concentration of NO would be converted into peroxynitrite $\left(\mathrm{ONOO}^{-}\right)$, which would cause retinal damage [13, 14]. In a previous study performed in RPE cells, we have found that the anti-VEGF drugs, Aflibercept and Ranibizumab, which are widely used for the treatment of exudative AMD $[1,18]$, were able to increase NO production through the eNOS isoform activation in RPE cells cultured physiological conditions, while they caused opposite effects in RPE cells that underwent peroxidation. Those effects were related to the activation of intracellular signaling downstream Akt and extracellular-signal-regulated kinases 1/2 (ERK1/2) [19]. In spite of this, the cellular mechanisms and signaling pathways conferring the protective effect of the anti- VEGF agents are only partially understood. In particular and up to date, no information is available about the modulation of the cross-talk between RPE and vascular endothelial cells, which appears critical for the maintenance of the outer-retinal structure and function. Thus, in the present study, we have compared the effects of Aflibercept and Ranibizumab on NO release, mitochondria function, oxidative stress and proliferation by human RPE cells (ARPE-19 cell line) in co-culture with human umbilical vascular endothelial cells (HUVEC). The use of NOS inhibitor, phosphatidylinositol 3'-kinase (PI3K), ERK1/2 and p38 mitogen-activated protein kinase (p38 MAPK) blockers furthermore allowed us to examine the involvement of those intracellular pathways

\section{Materials and Methods}

Culture of RPE and HUVEC

Human retinal pigment epithelium (RPE) cell line, was obtained from the American Type Culture Collection (ATCC; Rockville, Maryland, USA; catalog. no. CRL-2302 ${ }^{\mathrm{TM}}$; ARPE-19), and was maintained in Dulbecco's modified Eagle's medium (DMEM; Sigma, Milan, Italy) supplemented with 10\% fetal bovine 


\section{Cellular Physiology Cell Physiol Biochem 2020;54:161-179

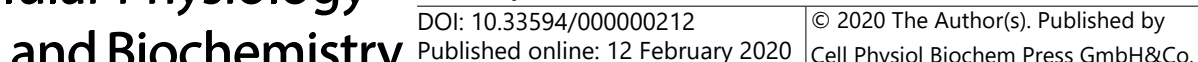 \\ Published online: 12 February 2020 Cell Physiol Biochem Press GmbH\&Co. KG \\ De Cillà et al.: Anti Vascular Endothelial Growth Factors and Retinal Function}

serum (FBS; Euroclone, Pero, Milan, Italy), and $2 \mathrm{mM}$ L-glutamine (Euroclone), 1\% penicillin-streptomycin (P/S; Euroclone), at $37^{\circ} \mathrm{C}$ with $5 \% \mathrm{CO}_{2}$ in incubator. Human umbilical vein endothelial cell line (HUVEC), was purchased from ATCC (catalog. no. CRL-1730 ${ }^{\mathrm{TM}}$ ), and was maintained in Kaighn's Modification of Ham's F-12 Medium (F-12K Medium; ATCC), containing $2 \mathrm{mM}$ L-glutamine, $1500 \mathrm{mg} / \mathrm{L}$ sodium bicarbonate, and supplemented with $0.1 \mathrm{mg} / \mathrm{ml}$ heparin (Sigma), $100 \mu \mathrm{g} / \mathrm{ml}$ endothelial cell growth supplement (ECGS; Sigma), $1 \% \mathrm{P} / \mathrm{S}$, and $10 \%$ FBS.

\section{Experimental protocol}

For co-culture experiments, HUVEC were plated in the apical compartment of the insert, while RPE cells were plated in the basal compartment. Transwell inserts were used by initially adding medium to the multi-well plate, which was followed by addition of the Transwell inserts, and lastly of the medium and cells to the inside compartment. After an initial equilibration period useful to improve cell attachment, the plate was then incubated for at least one hour at the same temperature used to grow the cells. The cells were then added in fresh medium to the Transwell inserts and returned to the incubator over-night. Next day, HUVEC were stimulated with Aflibercept $(0.025 \mathrm{mg} / \mathrm{ml}$ and $0.5 \mathrm{mg} / \mathrm{ml}$, for $30 \mathrm{~min})$ and Ranibizumab $(0.025 \mathrm{mg} /$ $\mathrm{ml}$ and $0.5 \mathrm{mg} / \mathrm{ml}$, for $30 \mathrm{~min})$. In addition, in some experiments, Aflibercept $(0.5 \mathrm{mg} / \mathrm{ml})$ and Ranibizumab $(0.5 \mathrm{mg} / \mathrm{ml})$ were also given after pre-treatment with the NOS inhibitor, L-NAME ( $4 \mu \mathrm{M}$, for $15 \mathrm{~min}$; Sigma), the p38 MAPK inhibitor, SB203580 (4 $\mu \mathrm{M}$, for $30 \mathrm{~min}$; Sigma), the phosphatidylinositol 3'-kinase (PI3K) inhibitor, wortmannin ( $4 \mu \mathrm{M}$, for $15 \mathrm{~min}$; Sigma), or the MAPK/ERK inhibitor, U0126 (4 $\mu \mathrm{M}$, for 15 min; Sigma). After the treatment, the medium was changed and newly completed fresh medium was added for $24 \mathrm{~h}$, in order to give the HUVEC time enough to induce any responses from the RPE cells. Next day, all Transwell inserts were removed by using sterile forceps, and some samples of RPE cells were also treated with $200 \mathrm{\mu M} \mathrm{H}_{2} \mathrm{O}_{2}$ for $30 \mathrm{~min}$, in order to induce oxidative stress. At the end of stimulations, various assays were performed. All experiments were conducted in triplicate and repeated at least five times.

\section{NO release}

NO production was measured in RPE cells culture supernatants by using the Griess method (Promega, Milan, Italy), as previously performed in the same or similar cellular models [19-24]. For the experiments, 7500 cells for well/insert were plated in 96-Transwell plates. HUVEC were stimulated with Aflibercept $(0.025 \mathrm{mg} / \mathrm{ml}$ and $0.5 \mathrm{mg} / \mathrm{ml}$, for $30 \mathrm{~min})$ and Ranibizumab $(0.025 \mathrm{mg} / \mathrm{ml}$ and $0.5 \mathrm{mg} / \mathrm{ml}$, for $30 \mathrm{~min})$. Another pool of cells was treated with Aflibercept $(0.5 \mathrm{mg} / \mathrm{ml}$, for $30 \mathrm{~min})$ and Ranibizumab $(0.5 \mathrm{mg} / \mathrm{ml}$, for $30 \mathrm{~min}$ ), after pre-treatment with various inhibitors, as described above. Next day, some RPE cell samples were treated with $200 \mu \mathrm{M} \mathrm{H}_{2} \mathrm{O}_{2}$ for $30 \mathrm{~min}$. At the end of the stimulations, NO production in the sample's supernatants was examined by adding an equal volume of Griess reagent following the manufacturer's instruction. At the end of incubation, the absorbance at $570 \mathrm{~nm}$ was measured by a spectrometer (VICTOR ${ }^{\mathrm{TM}}$ X Multilabel Plate Reader; PerkinElmer; Waltham, Massachusetts, USA) and the NO production. The value of each sample was quantified in respect to nitrite standard curve and expressed as nitrite production $(\mu \mathrm{M})$.

\section{Cell viability}

Cell viability was examined in RPE cells by using the 1\% 3-[4, 5-dimethylthiazol-2-yl]-2, 5-diphenyl tetrazolium bromide (MTT; Life Technologies Italia, Monza, Italy) dye, as previously described [19-25]. For the experiments, 10000 cells for well/insert were plated in 96-Transwell plates and treated as described for Griess assay. After each treatment, the medium was removed, and fresh culture medium without red phenol and FBS and with $0,5 \mathrm{mg} / \mathrm{ml}$ MTT dye was added to the 96 -well plate containing the cells that were kept for $2 \mathrm{~h}$ at $37^{\circ} \mathrm{C}$ in an incubator. Thereafter, the medium was removed, and an MTT solubilization solution (dimethyl sulfoxide; DMSO; Sigma) in equal volume to the original culture medium was added and mixed in a gyratory shaker until the complete dissolution of formazan crystals. Cell viability was determined by measuring the absorbance through a spectrometer (VICTOR ${ }^{\mathrm{TM}}$ X Multilabel Plate Reader; PerkinElmer) with a wavelength of $570 \mathrm{~nm}$ and cell viability was calculated by setting control cells as $100 \%$.

\section{Mitochondrial membrane potential}

Mitochondrial membrane potential measurement in RPE cells was performed with JC-1 assay, as previously described [19, 21, 23-25] and following the experimental protocol used for MTT assay. After stimulations, the medium of cells plated in starvation medium was removed and the cells were incubated 


\section{Cellular Physiology Cell Physiol Biochem 2020;54:161-179 \begin{tabular}{ll|l} 
and Biochemistry & Published online: 12 February 2020 & C) 2020 The Author(s). Published by \\
Cell Physiol Biochem Press GmbH\&Co. KG
\end{tabular} \\ De Cillà et al.: Anti Vascular Endothelial Growth Factors and Retinal Function}

with 5, 51, 6,61-tetrachloro-1, 11, 3,31 tetraethylbenzimidazolyl carbocyanine iodide (JC-1) 1X diluted in Assay Buffer $1 \mathrm{X}$ for $15 \mathrm{~min}$ at $37^{\circ} \mathrm{C}$ in an incubator, following the manufacturer's instruction (Cayman Chemical, Ann Arbor, MI, USA). After incubation, the cells were washed twice with Assay Buffer $1 \mathrm{X}$ and then the mitochondrial membrane potential was determined by measuring the red (excitation $550 \mathrm{~nm} / \mathrm{emission}$ $600 \mathrm{~nm}$ ) and green (excitation $485 \mathrm{~nm} /$ emission $535 \mathrm{~nm}$ ) fluorescence through a spectrometer (VICTOR ${ }^{\mathrm{TM}}$ $\mathrm{X}$ Multilabel Plate Reader; PerkinElmer). To identify cells undergoing apoptosis, the ratio of fluorescent intensity of J-aggregates to fluorescent intensity of monomers was used as an indicator of cell health. The data were normalized versus control cells.

\section{Wound-healing migration}

Cell migration was measured in RPE cells, as previously described [24]. For the experiments, 25000 cells for well/insert were plated in 24-Transwell plate. HUVEC were stimulated with Aflibercept (0.025 mg/ $\mathrm{ml}$ and $0.5 \mathrm{mg} / \mathrm{ml}$, for $30 \mathrm{~min})$ and Ranibizumab $(0.025 \mathrm{mg} / \mathrm{ml}$ and $0.5 \mathrm{mg} / \mathrm{ml}$, for $30 \mathrm{~min})$. Images of cell monolayers were taken using an optical microscope (Leica ICC50HD) with a digital camera to evaluate wound closure. Migration was quantified by calculating the area of wound at time points T0 (time of wound), T24 (24 h after wound) and T48 (48 h after wound) by using Image J software (National Institutes of Health, Bethesda, MA, USA). For each condition, the percentage of wound closure at several time points throughout the course of the assay, was obtained through the formula:

$\%$ wound closure: [WA0-WA/ WA0 $]^{*} 100$, where WA= wound area and WA $0=$ original size of the wound area.

\section{ROS release}

The ROS generation was performed with a specific kit (Abcam, Cambridge, United Kingdom) [19, 21-24]. For the experiments, 25000 cells for well/insert were plated in 96-Transwell plate and the same protocol used for Griess, MTT and JC-1 methods was followed, but in the absence of inhibitors. Briefly, after treatments, the reactions were stopped by removing the medium and washing the cells with PBS which was followed by staining with $10 \mu \mathrm{M}$ H2DCFDA for $20 \mathrm{~min}$ at $37^{\circ} \mathrm{C}$. The fluorescence intensity of DCF was measured at an excitation and emission wavelength of $485 \mathrm{~nm}$ and $530 \mathrm{~nm}$, respectively, by using a spectrophotometer (VICTOR ${ }^{\mathrm{TM}}$ X Multilabel Plate Reader; PerkinElmer). The amount of intracellular ROS was proportional to the intensity of DCF fluorescence, and the fluorescence intensity was recorded directly to indicate the relative amount of ROS. Results were expressed as DCF fluorescence intensity, which was proportional to the amount of intracellular ROS.

\section{Glutathione (GSH) quantification}

GSH measurement was performed with a specific kit (Cayman Chemical) as previously described [19, $21,24,25]$. For the experiments, 400000 cells for well/insert were plated in 6-Transwell plate. HUVEC were treated as described for ROS quantification. Briefly, after treatments, cells were lysed by using the $50 \mathrm{mM}$ 2-(N-morpholino) ethanesulphonic acid (GSH MES Buffer) and a rubber policeman, and were centrifuged at $10000 \mathrm{~g}$ for $15 \mathrm{~min}$ at $4^{\circ} \mathrm{C}$. After centrifugation, the supernatant was treated with an equal volume of metaphosphoric acid (Sigma) for $5 \mathrm{~min}$ and centrifuged at $2000 \mathrm{~g}$ for at least two min. The supernatant was collected and supplemented with $50 \mu \mathrm{l}$ per $\mathrm{ml}$ of $4 \mathrm{M}$ solution of triethanolamine (Sigma). Fifty $\mu \mathrm{l}$ of the samples was transferred to a 96-well plate where GSH was detected following the manufacturer's instructions through a spectrometer (VICTOR ${ }^{\mathrm{TM}}$ X Multilabel Plate Reader; PerkinElmer) at excitation/ emission wavelengths of 405-414 nM. Glutathione was expressed as GSH production $(\mu \mathrm{M})$.

\section{Cell proliferation}

The RPE cell proliferation was performed with xCELLigence ${ }^{\mathrm{TM}}$ MP Instrument (Roche, Basel, Switzerland) [19]. For the experiments, 3000 cells for well/ insert were plated in 16-well E-plate. HUVEC were stimulated with Aflibercept $(0.5 \mathrm{mg} / \mathrm{ml}$, for $30 \mathrm{~min})$ and Ranibizumab $(0.5 \mathrm{mg} / \mathrm{ml}$, for $30 \mathrm{~min})$. After stimulations, the medium of HUVEC was changed and new F-12K medium was added. At the same time and in order to induce peroxidation, some RPE cells were treated with $200 \mu \mathrm{M} \mathrm{H}_{2} \mathrm{O}_{2}$, which was left to act all the time of the analysis. The proliferation rate was determined by the Cell Index, and analyzed after $12 \mathrm{~h}, 24 \mathrm{~h}$ and $48 \mathrm{~h}$.

Cell-sensor impedance was expressed as an arbitrary unit called the Cell Index. The Cell Index at each time point is defined as (Rn-Rb)/15, where $\mathrm{Rn}$ is the cell-electrode impedance of the well when it 


\section{Cellular Physiology Cell Physiol Biochem 2020;54:161-179

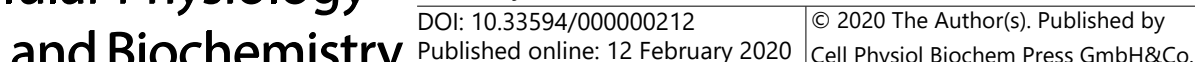 \\ Published online: 12 February 2020 Cell Physiol Biochem Press GmbH\&Co. KG \\ De Cillà et al:: Anti Vascular Endothelial Growth Factors and Retinal Function}

contains cells and $\mathrm{Rb}$ is the background impedance of the well with the media alone. The system measures the electrical impedance across interdigitated microelectrodes integrated at the bottom of E-plates. The data were analyzed with real-time cell analysis (RTCA) software, which includes real-time data display and analysis functions.

\section{Cell cycle analysis}

Flow cytometry was used for cell cycle analysis, as previously described [24]. For the experiments, 400000 cells for well/insert were plated in 6-Transwell plates. HUVEC were stimulated with Aflibercept $(0.5 \mathrm{mg} / \mathrm{ml}$, for $30 \mathrm{~min})$ and Ranibizumab $(0.5 \mathrm{mg} / \mathrm{ml}$, for $30 \mathrm{~min})$. Next day, some RPE cell samples were treated with $200 \mu \mathrm{M} \mathrm{H}_{2} \mathrm{O}_{2}$ for $30 \mathrm{~min}$, in order to induce oxidative stress. At the end of each stimulations, the culture medium was collected from each well and transferred into a $15 \mathrm{ml}$ tube in order to collect the cells that were eventually detached, through trypsin-EDTA. Thereafter, an appropriate volume of culture medium was added, and cell suspension was transferred into a tube and centrifuged at $900 \mathrm{~g}$ for $5 \mathrm{~min}$ at room temperature. The supernatant was discarded, and cells were fixed in $1 \mathrm{ml} 70 \%$ ethanol for $1 \mathrm{~h}$ at $-20^{\circ} \mathrm{C}$. After $1 \mathrm{~h}$, the cells were centrifuged at $900 \mathrm{~g}$ for $5 \mathrm{~min}$, and ethanol, as well as, the supernatants were discarded. Cells were washed with PBS and centrifuged again $900 \mathrm{~g}$ for $5 \mathrm{~min}$. Each pellet of cells was resuspended in $200 \mu \mathrm{l}$ propidium iodide buffer ( $3.4 \mathrm{mM}$ trisodium citrate, $9.65 \mathrm{mM}$ sodium chloride, $0.003 \%$ tergitol), $25 \mu \mathrm{l}$ RNasi A (10 ng/ml; Cabru), and $10 \mu \mathrm{l}$ propidium iodide ( $1 \mathrm{mg} / \mathrm{ml}$; Cabru).

Then, $50 \mu \mathrm{l}$ of each sample was transferred in a 96-well plate in triplicate, and after $15 \mathrm{~min}$ at $37^{\circ} \mathrm{C}$ in the dark, the analysis was performed by using Attune NxT (Life Technologies).

\section{Cell lysates}

For protein expression/activation, HUVEC were stimulated as described for cell cycle analysis. For the experiments, 400000 cells for well/insert were plated in 6-Transwell plates. At the end of stimulation, RPE cells were lysed in iced Ripa buffer, as described previously [19, 21-25].

\section{Western blot analysis}

Cell lysates (30 $\mu \mathrm{g}$ of each protein sample) were loaded onto sodium dodecyl sulfate polyacrylamide gel electrophoresis and, thereafter, they were transferred to polyvinylidene fluoride membranes (BioRad Laboratories), which were incubated with specific primary antibodies: anti phospho-eNOS (1:1000; Ser1177, Cell Signaling Technologies), anti eNOS (1:1000; Cell Signaling Technologies), anti iNOS (1:500; Santa Cruz Biotechnology), anti phospho-Akt (1:1000; Ser 473, Santa Cruz Biotechnology), anti Akt (1:1000; Santa Cruz Biotechnology) anti phospho-ERK 1/2 (1:1000; Thr 202/Tyr 204, Santa Cruz Biotechnology), anti ERK 1/2 (1:1000; Santa Cruz Biotechnology), anti Cleaved Caspase-9 (1:1000; Abcam, Cambridge, UK) and anti Cytochrome C (1:1000, Santa Cruz Biotechnology). The membranes were washed and incubated with horseradish peroxidase-coupled goat anti-rabbit IgG (Sigma), peroxidase-coupled rabbit anti-goat IgG and horseradish peroxidase-coupled goat anti-mouse IgG (Sigma) for $45 \mathrm{~min}$ and were developed through Western Lightning Chemiluminescence (PerkinElmer Life and Analytical Sciences). Protein expression was calculated as a ratio towards specific total protein expression or $\beta$-actin (1:5000; Santa Cruz Biotechnology) detection.

\section{Statistical analysis}

All data were recorded using the Institution's database. Statistical analysis was performed by using STATVIEW version 5.0.1 for Microsoft Windows (SAS Institute Inc., Cary NC, USA). Data were checked for normality before statistical analysis. All the results obtained were examined through one-way ANOVA followed by Bonferroni post hoc tests. All data are presented as means \pm standard deviation (SD) of five independent experiments for each experimental protocol. A value of $\mathrm{P}<0.05$ was considered statistically significant. 


\section{Cellular Physiology Cell Physiol Biochem 2020;54:161-179 \\ \begin{tabular}{ll|ll} 
and Biochemistry & $\begin{array}{l}\text { DOl: 10.33594/000000212 } \\
\text { Published online: } 12 \text { February 2020 }\end{array}$ & $\begin{array}{l}\text { O 2020 The Author(s). Published by } \\
\text { Cell Physiol Biochem Press GmbH\&Co. KG }\end{array}$ \\
\cline { 2 - 3 }
\end{tabular} \\ De Cillà et al.: Anti Vascular Endothelial Growth Factors and Retinal Function}

\section{Results}

Effects of Aflibercept and Ranibizumab administrated to HUVEC/RPE cells co-culture on cell viability, mitochondrial membrane potential and NO release in RPE cells

As illustrated in Fig. 1A and C, in physiological conditions the HUVEC treatment induced a dose-dependent increase of NO release in RPE cells, while reducing the NO release caused by peroxidation (Fig. 1B and D). It is notable that the pre-treatment with inhibitors counteracted the effects of Aflibercept and Ranibizumab on NO release, in both physiological conditions (Fig. 1A and C), and peroxidation (Fig. 1B and D).

In physiological conditions the administration of Aflibercept and Ranibizumab to HUVEC/RPE cells co-culture caused a dose-response increase in RPE cells viability (Fig. $2 \mathrm{~A}$ and $\mathrm{C}$ ). Similar effects were observed as regarding mitochondrial membrane potential (Fig. 3A and C); however, in this case, while both doses Aflibercept were able to induce an increase, the same effect was observed with $0.5 \mathrm{mg} / \mathrm{ml}$ Ranibizumab, only. In peroxidative conditions, both anti VEGF agents prevented the reduction of cell viability (Fig. 2B and D) and the collapse of mitochondrial membrane potential (Fig. 3B and D) caused by $\mathrm{H}_{2} \mathrm{O}_{2}$ in RPE cells. Of note, in physiological and peroxidative conditions, the protective effects elicited by HUVEC treated with Aflibercept and Ranibizumab on RPE cells, were reduced or abolished by U0126, wortmannin, SB203580 and L-NAME (Fig. 2 and 3).

Changes of activation/expression of eNOS/iNOS, Akt, ERK1/2, Cleaved Caspase 9 and Cytochrome $C$ in RPE cells in co-culture with HUVEC treated with Aflibercept and Ranibizumab

As shown in Fig. 4, the effects of co-culture HUVEC/RPE cells on NO release by RPE cells, were accompanied by changes in eNOS/iNOS activation/expression. In physiological conditions, eNOS phosphorylation was increased (Fig. 4A), while iNOS expression was reduced (Fig. 4B). In RPE cells subjected to peroxidation, both kinases activation/expression were inhibited.

As shown in Fig. 5A and B, the treatment of HUVEC with Aflibercept and Ranibizumab increased p-Akt and p-ERK1/2 in RPE cells cultured in physiological conditions and prevented their inhibition caused by hydrogen peroxide.

In addition, the anti VEGF drugs were able to counteract the effects of hydrogen peroxide on apoptosis in RPE cells (Fig. 5C and D).

Effects of Aflibercept and Ranibizumab administration to HUVEC/RPE cells co-culture on ROS and GSH production by RPE cells

The stimulation of HUVEC with the two anti-VEGF drugs, reduced ROS production by RPE cells in a dose-dependent manner with a maximum effect at $0.5 \mathrm{mg} / \mathrm{ml}$ for Aflibercept and $0.2 \mathrm{mg} / \mathrm{ml}$ for Ranibizumab (Fig. 6A). Moreover, as shown in Fig. 6B, an increase in GSH production was observed with both anti-VEGF drugs.

Effects of Aflibercept and Ranibizumab administration to HUVEC/RPE cells co-culture on RPE cells migration and proliferation

As shown in Fig. 7A and B, Aflibercept and Ranibizumab increased RPE cells migration with a maximum effect at the major dose until $24 \mathrm{~h}$ from the wound. Furthermore, in physiological conditions, HUVEC stimulated with Aflibercept and Ranibizumab, were able to increase RPE cells proliferation (Fig. 7C) only up to $12 \mathrm{~h}$ of stimulation, while, after $24 \mathrm{~h}$ and $48 \mathrm{~h}$, cell proliferation was reduced in a time-dependent way. Both agents counteracted the effects of hydrogen peroxide (Fig. 7D) from $12 \mathrm{~h}$ to $48 \mathrm{~h}$ of stimulation, too. 


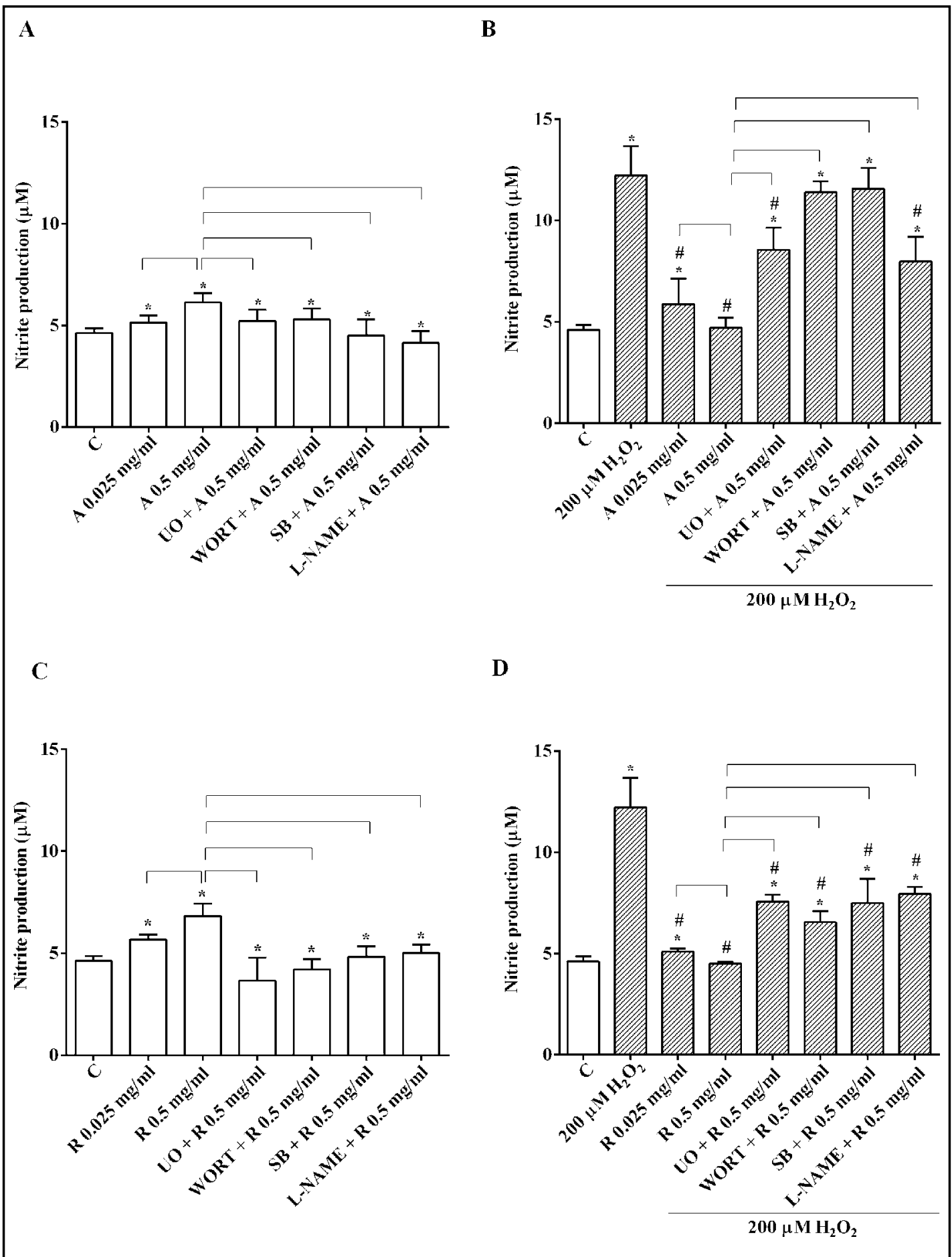

Fig. 1. Effects of HUVEC/RPE cells co-culture on NO release in RPE cells, in physiological (A and C) or peroxidative ( $B$ and $D$ ) conditions. In $A$ and $B$, the effects of Aflibercept $(A)$, and in $C$ and $D$, the effects of Ranibizumab (R), are shown. The values obtained correspond to the nitrite $(\mu \mathrm{M})$ produced after each stimulation. $\mathrm{C}=$ control (non- treated cells). UO (U0126 $4 \mu \mathrm{M}$ for $15 \mathrm{~min}$ ); WORT (wortmannin $4 \mu \mathrm{M}$ for $15 \mathrm{~min}$ ); SB (SB203580 $4 \mu \mathrm{M}$ for $15 \mathrm{~min}$ ); L-NAME ( $4 \mu \mathrm{M}$ for $15 \mathrm{~min}$ ). Reported data are means \pm SD of five independent experiments for each experimental protocol. Significance between groups: ${ }^{*} \mathrm{P}<0.05$ vs $\mathrm{C}$; $\# \mathrm{P}<0.05$ vs $200 \mu \mathrm{M} \mathrm{H}_{2} \mathrm{O}_{2}$. Short square brackets indicate significance between groups $(\mathrm{P}<0.05)$. 


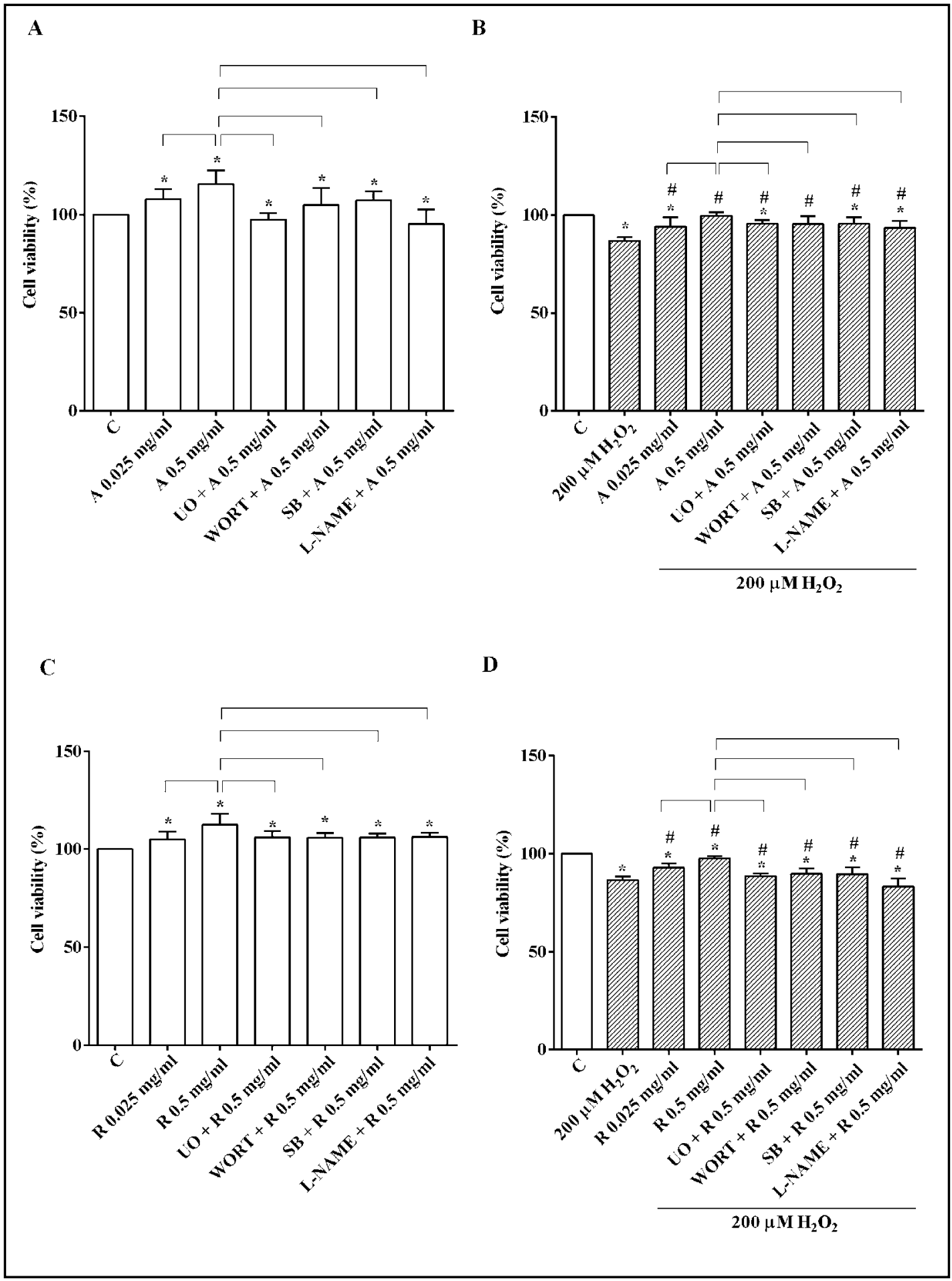

Fig. 2. Effects of HUVEC/RPE cells co-culture on RPE cell viability in physiological (A and $C$ ) and peroxidative (B and D) conditions. In A and B, the effects of Aflibercept, and in C and D, the effects of Ranibizumab, are shown. Abbreviations are as in the previous Fig.. The data were normalized versus control value. Reported data are means \pm SD of five independent experiments for each experimental protocol. Significance between groups: ${ }^{*} \mathrm{P}<0.05$ vs $\mathrm{C}$; $\# \mathrm{P}<0.05$ vs $200 \mu \mathrm{M} \mathrm{H}_{2} \mathrm{O}_{2}$. Short square brackets indicate significance between groups $(\mathrm{P}<0.05)$. 


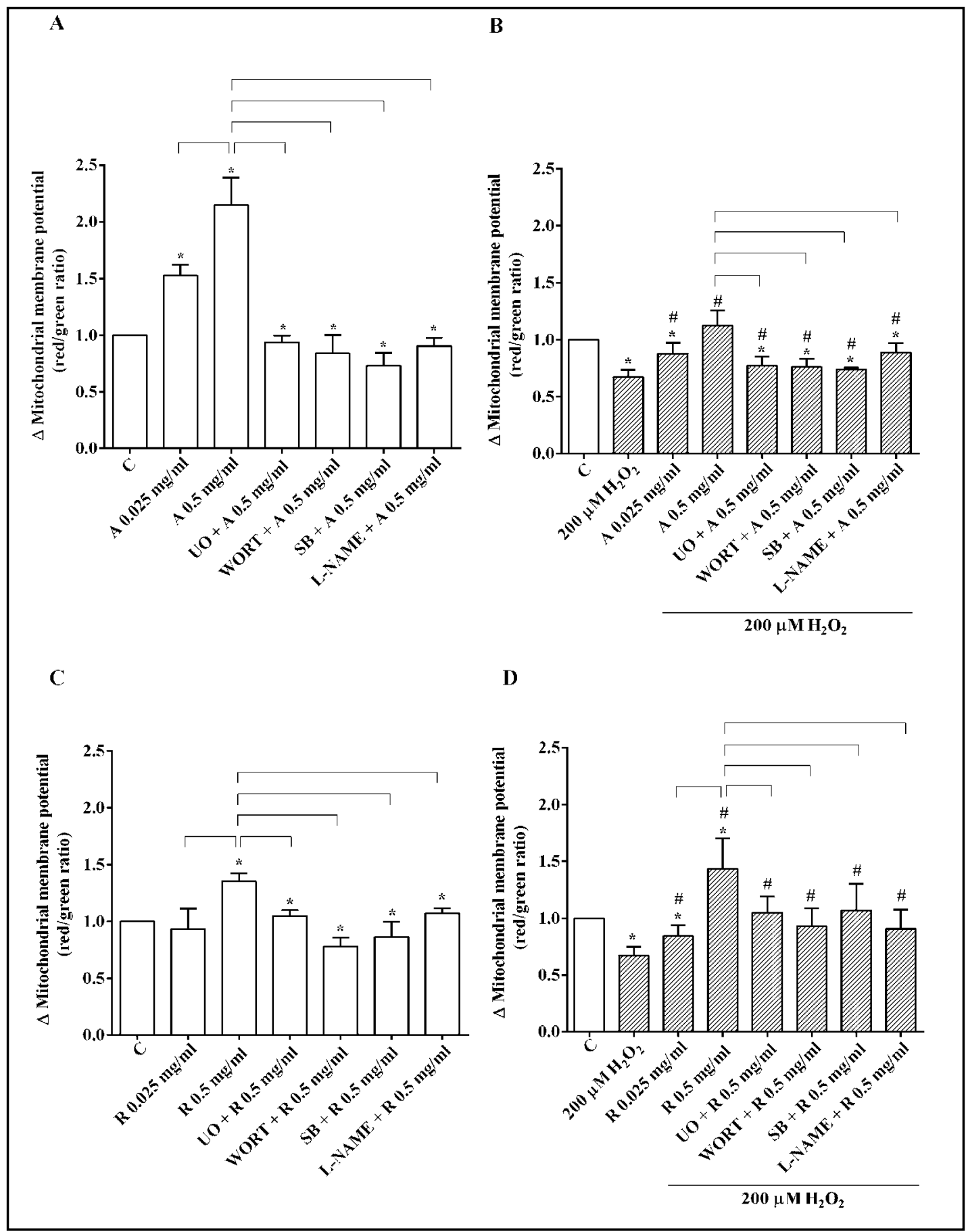

Fig. 3. Effects of HUVEC/RPE cells co-culture on mitochondrial membrane potential in RPE cells, in physiological (A and C) and peroxidative (B and D) conditions. In A and B, the effects of Aflibercept, and in $C$ and $D$, the effects of Ranibizumab, are shown. Abbreviations are as in previous Fig.s. The data were normalized versus control value. Reported data are means \pm SD of five independent experiments for each experimental protocol. Significance between groups: ${ }^{*} \mathrm{P}<0.05$ vs $\mathrm{C}$; $\# \mathrm{P}<0.05$ vs $200 \mu \mathrm{M} \mathrm{H}_{2} \mathrm{O}_{2}$. Short square brackets indicate significance between groups $(\mathrm{P}<0.05)$. 
Fig. 4. Variation in eNOS phosphorylation and iNOS expression measured in RPE cells by Western blot and densitometric analysis. In A and B, densitometric analysis and an example of Western blot of p-eNOS and iNOS are respectively shown. Abbreviations are as in previous Fig.s. The data were normalized versus control cells. Reported data are means \pm SD of five independent experiments for each experimental protocol. Significance between groups: ${ }^{*} \mathrm{P}<0.05$ vs $\mathrm{C}$; $\# \mathrm{P}<0.05$ vs $200 \mu \mathrm{M} \mathrm{H}_{2} \mathrm{O}_{2}$.
A
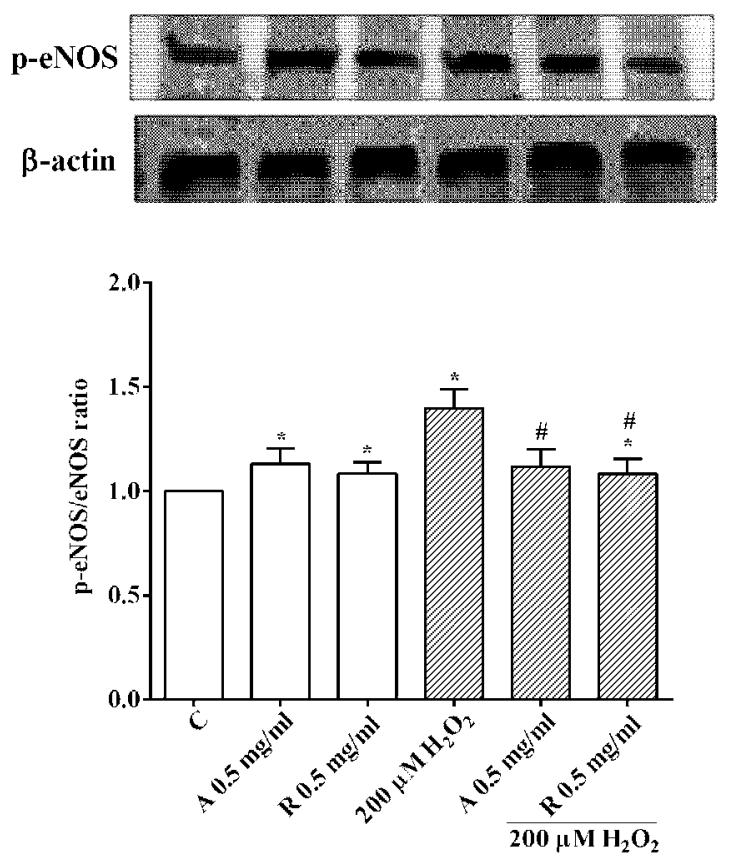

B
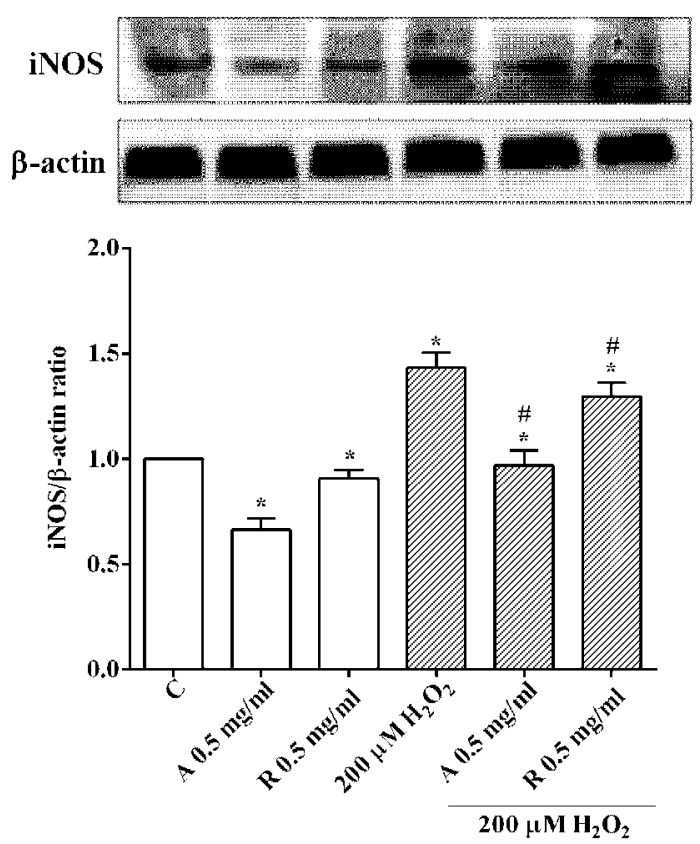


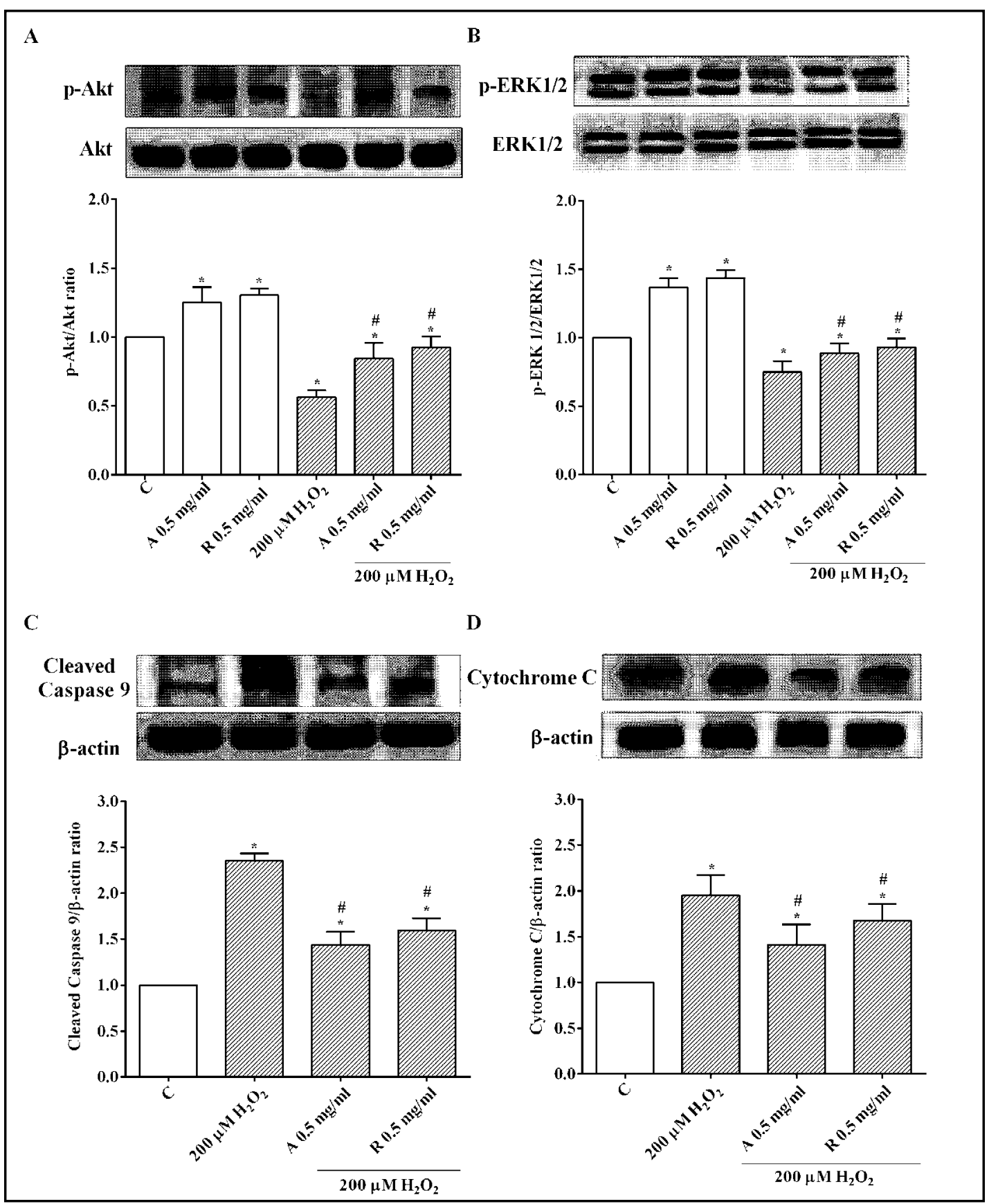

Fig. 5. Variation in Akt and ERK 1/2 phosphorylation (A and B) and in Cleaved Caspase 9 and Cytochrome $\mathrm{C}$ expression ( $C$ and D) in RPE cells, measured by Western blot and densitometric analysis. Densitometric analysis and an example of Western blot taken from 5 different experiments are shown in Fig.s A and B for p-Akt and p-ERK1/2, respectively, and in C and D for Cleaved Caspase 9 and Cytochrome C, respectively. Abbreviations are as in previous Fig.s. The data were normalized versus control value. Reported data are means \pm SD of five independent experiments for each experimental protocol. Significance between groups: ${ }^{*} \mathrm{P}<0.05$ vs $\mathrm{C} ; \# \mathrm{P}<0.05$ vs $200 \mu \mathrm{M} \mathrm{H}_{2} \mathrm{O}_{2}$. 
Fig. 6. Effects of HUVEC/RPE cells co-culture on ROS (A) and GSH (B) production in RPE cells. Abbreviations are as in previous Fig.s. In A, results are expressed as DCF fluorescence intensity, which is proportional to the amount of intracellular ROS. In B, results are expressed as GSH $(\mu \mathrm{M})$ produced after each stimulation. Reported data are means \pm SD of five independent experiments for each experimental protocol. Significance between groups: ${ }^{*} \mathrm{P}<0.05$ vs $\mathrm{C}$; $\# \mathrm{P}<0.05$ vs 200 $\mu \mathrm{M} \mathrm{H}_{2} \mathrm{O}_{2}$. Short square brackets indicate significance between groups $(\mathrm{P}<0.05)$.
A

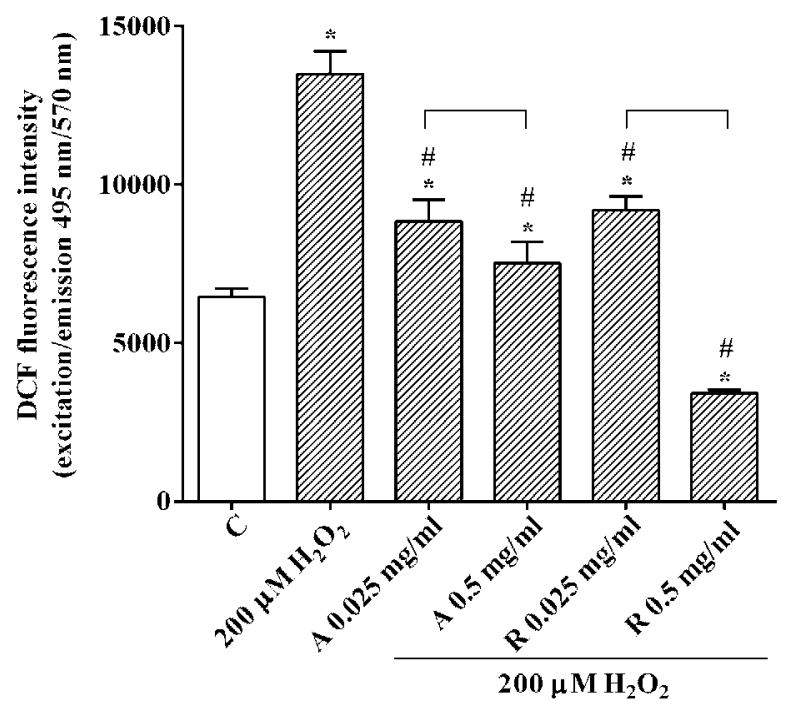

B

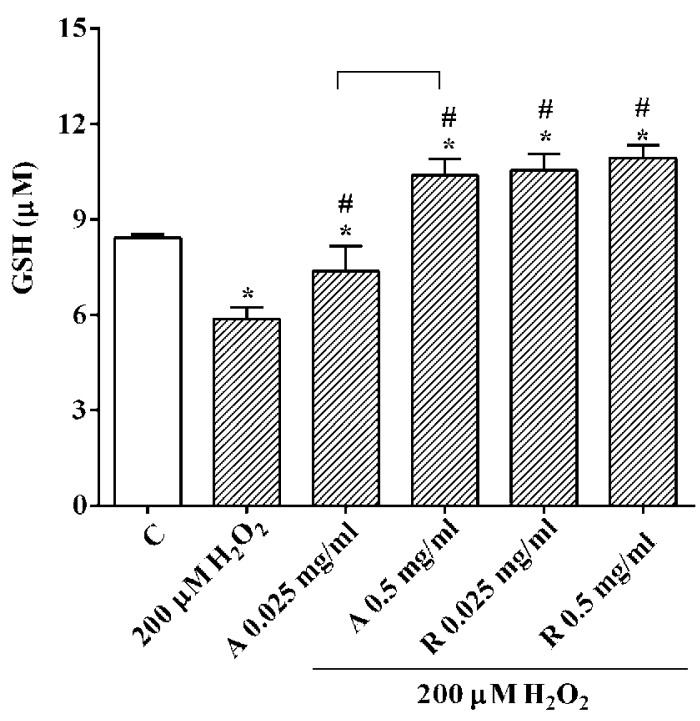


A

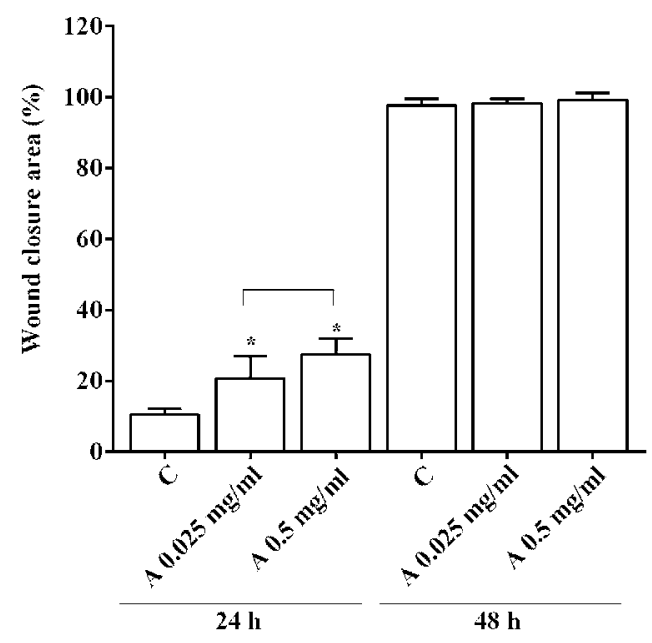

$\mathrm{C}$

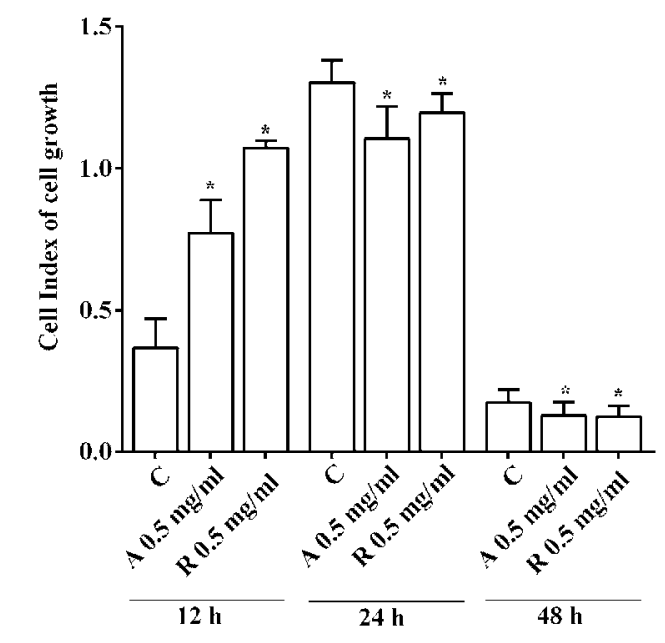

B

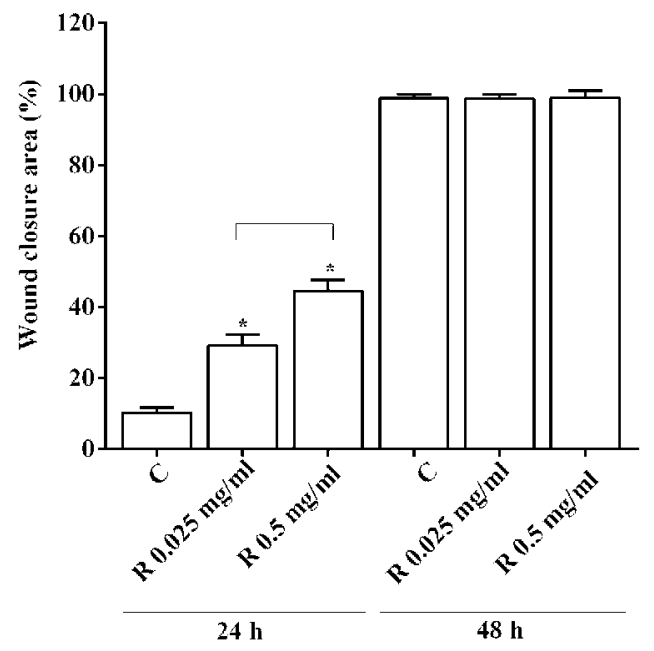

D

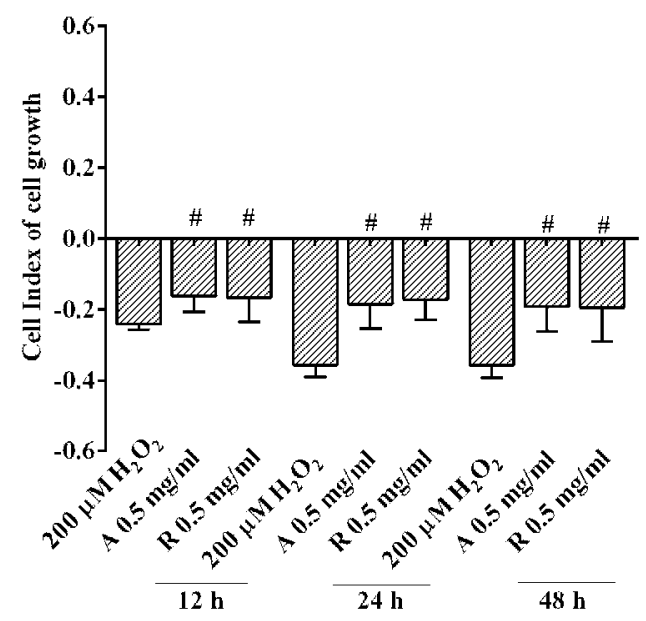

Fig. 7. Effects of HUVEC/RPE cells co-culture on RPE proliferation (A and B) and RPE migration (C and D). Abbreviations are as in previous Fig.s. In A (Aflibercept) and B (Ranibizumab), quantified data for the wound-healing assay are shown. The wound area and the percentage of healing were calculated for each time point. In C (physiological condition) and D (peroxidative condition), Cell index obtained from the xCELLigence system is shown. Abbreviations are as in previous Fig.s. Reported data are means \pm SD of five independent experiments for each experimental protocol. Significance between groups: ${ }^{*} \mathrm{P}<0.05$ vs C; $\# \mathrm{P}<0.05$ vs $200 \mu \mathrm{M} \mathrm{H}_{2} \mathrm{O}_{2}$. Short square brackets indicate significance between groups $(\mathrm{P}<0.05)$. 
Fig. 8. Effects of HUVEC/ RPE cells co-culture on RPE cell cycle progression, in physiological (A) and peroxidative (B) conditions. Cell cycle distribution was measured by flow cytometry using propidium iodide stain and quantitative analysis of apoptosis, G0/ G1, synthesis, and G2/M phase is shown in a bar graph form. Abbreviations are as in previous Fig.s. Reported data are means \pm SD of five independent experiments for each experimental protocol. Significance between groups: ${ }^{*} \mathrm{P}<0.05$ vs $\mathrm{C} ; \# \mathrm{P}<0.05$ vs $200 \mu \mathrm{M} \mathrm{H} \mathrm{H}_{2} \mathrm{O}_{2}$. Short square brackets indicate significance between groups $(\mathrm{P}<0.05)$.

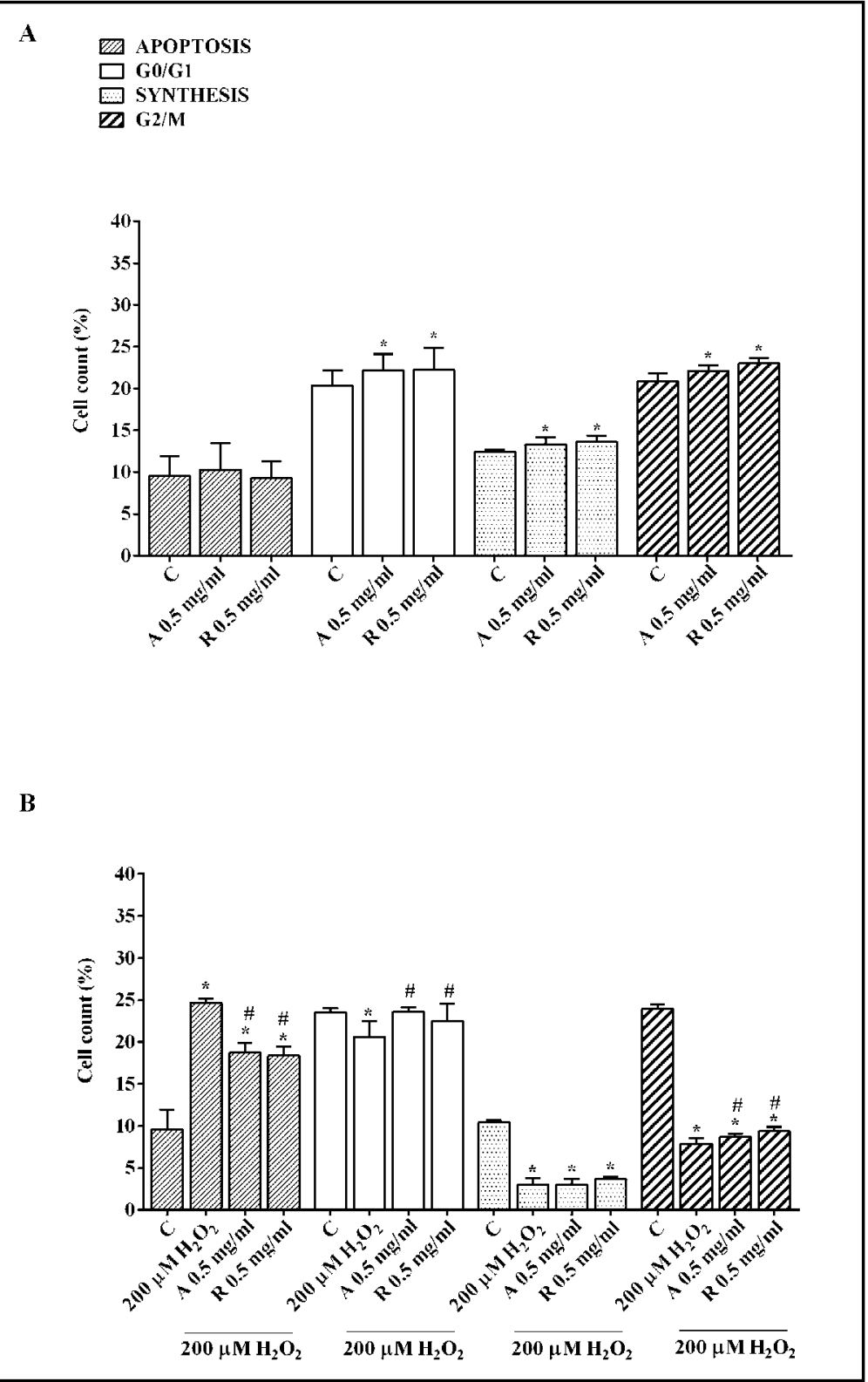

Effects of Aflibercept and Ranibizumab administration to HUVEC/RPE cells co-culture on RPE cell cycle

The effects observed previously, were partly confirmed by the cell cycle analysis. Thus, in physiological conditions, HUVEC stimulated with Aflibercept and Ranibizumab, increased the percentage of RPE cells in G0/G1, S and G2/M phase (Fig. 8A). In peroxidative conditions, HUVEC stimulated with both anti-VEGF drugs, reduced the percentage of RPE cells in apoptosis. Moreover, in comparison with hydrogen peroxide, Aflibercept and Ranibizumab were able to increase the percentage of RPE cells in G0/G1 AND G2/M (Fig. 8B). 


\section{Cellular Physiology Cell Physiol Biochem 2020;54:161-179 \\ \begin{tabular}{ll|l} 
and Biochemistry & $\begin{array}{l}\text { DOI: } 10.33594 / 000000212 \\
\text { Published online: } 12 \text { February } 2020\end{array}$ & $\begin{array}{l}\text { C } 2020 \text { The Author(s). Published by } \\
\text { Cell Physiol Biochem Press GmbH\&Co. KG }\end{array}$
\end{tabular} \\ De Cillà et al.: Anti Vascular Endothelial Growth Factors and Retinal Function}

\section{Discussion}

This study has shown for the first time that anti-VEGF agents, Aflibercept and Ranibizumab, play an important role in the modulation of cell viability, mitochondrial membrane potential, proliferation and migration of RPE cells co-cultured with HUVEC, in either physiological or pathological conditions, by mechanisms related to NO release and cell survival-related pathways.

In a previous study, Aflibercept and Ranibizumab were able to increase the NO release by RPE cells cultured in physiological conditions and to cause opposite results in peroxidation. Moreover, beneficial effects on cell viability and mitochondrial function were observed [19]. However, since the normal interaction between RPE cells and retinal vascular endothelial cells appears critical for the maintenance of the outer-retinal structure and function [26, 27] and for the onset of vision-threatening pathological conditions such as AMD [28] a better characterization of the homeostatic RPE cells-vascular endothelial cells relationships would therefore be of particular interest [27].

Thus, in the present study we focused on the effects of the anti-VEGF drugs on the cross talk between RPE cells and HUVEC, which were directly treated with the two anti-VEGF drugs, at doses similar to the ones achievable in humans after intravitreal injections, and previously used in RPE cells $[19,29]$.

Moreover, since oxidative stress to RPE cells over time is theorized to produce tissue dysfunction that contributes to the development of AMD $[19,30] \mathrm{H}_{2} \mathrm{O}_{2}$ at a concentration which is widely adopted to induce oxidative stress in various cell lines, among which RPE $[19,31-33]$ was used in some experiments.

The results obtained confirmed our previous observations about NO release, cell viability and mitochondria function [19]. Hence, Aflibercept and Ranibizumab increased the NO release by RPE cells co-cultured in physiological conditions with HUVEC. Opposite results were obtained in peroxidation, when both Aflibercept and Ranibizumab reduced the NO release caused by hydrogen peroxide. These effects on NO release were accompanied by changes in eNOS/iNOS activation/expression.

Those findings would confirm the fact that differences of NO concentration and of activity of the constitutive or inducible NOS could account for the beneficial or harmful effects played by NO in RPE $[10,13,14]$.

It is also of note that the administration of the NOS blocker, L-NAME, reduced the effects of the anti VEGF drugs on cell viability and mitochondrial membrane potential of RPE cells co-cultured with HUVEC, which would highlight the role of NO in the determining these responses.

The findings we have obtained about the protective effects of anti-VEGF agents on mitochondrial membrane potential could be of significant clinical relevance. Mitochondrial membrane potential has been considered as a good indicator of the energetic status of the mitochondria and, above all, of cellular homeostasis. Interestingly, changes in mitochondrial membrane potential have been reported to be correlated with cell survival or death through apoptosis [34-37]. Previous data have shown a clear association between RPE cell health and compromised mitochondrial function $[33,38,39]$. In particular, mitochondrial depolarization has been reported to precede RPE cell death caused by peroxidation through the reduction of energy production, as well as, the increase in Cytochrome $C$ release and ROS [40-42].

In our study both anti-VEGF agents, in addition to preventing the fall of cell viability and mitochondrial membrane potential, were also able to increase cell proliferation and migration, and to counteract the effects of $\mathrm{H}_{2} \mathrm{O}_{2}$. These results were confirmed by cell cycle analysis, too.

The above findings could also be of particular relevance in clinical conditions. Hence, there are emerging indications that anti-VEGF treatment can potentially increase development of RPE cell atrophy leading to geographic atrophy (GA) [17, 42-45]. Our data showing protective effects elicited by anti-VEGF agents in RPE cell proliferation and migration are in contrast with findings reported from in vivo studies [46]. It could, however, be argued that 


\section{Cellular Physiology Cell Physiol Biochem 2020;54:161-179 \\ \begin{tabular}{ll|l} 
and Biochemistry $10.33594 / 000000212$ & Published online: 12 February 2020 & 2020 The Author(s). Published by \\
Cell Physiol Biochem Press GmbH\&Co. KG
\end{tabular} \\ De Cillà et al.: Anti Vascular Endothelial Growth Factors and Retinal Function}

the increased cell proliferation was observed in RPE cells with Aflibercept and Ranibizumab treatments up to $12 \mathrm{~h}$, only. Findings taken with longer exposure would be in agreement with previous data. Changes in ocular microenvironment or effects of the anti-VEGF agents on retinal cells other than RPE cells could contribute to those discrepancies. Although the exact mechanisms of anti-VEGF effect on macular atrophy has not been fully elucidated, data from the present study may indicate that the keeping of mitochondria function could be hypothesized to play a key role.

The protective effect of Aflibercept and Ranibizumab on RPE cells response to oxidative stress, has been confirmed by the analysis of ROS release and GSH content.

Oxidative stress is one of the leading factors triggering RPE cells apoptosis. Furthermore, while the accumulation of ROS in mitochondria can lead to apoptotic cell death and ROS, it may also have direct effects on cellular structure and function. In our study Aflibercept and Ranibizumab, were able to reduce ROS production induced by $\mathrm{H}_{2} \mathrm{O}_{2}$, to increase GSH content and to decrease apoptosis, as shown by Western blot. The keeping GSH content could be hypothesized to be involved in the modulation of eNOS function and ROS release. Hence, eNOS itself has been reported to be a redox "hub", being regulated by GSH-dependent pathways. Also, changes of GSH have been reported to cause eNOS "uncoupling", which would trigger ROS production from the oxygenase domain [47].

In our study, short-term exposure of RPE cells to $\mathrm{H}_{2} \mathrm{O}_{2}$ reduced Akt activation, as previously shown in the same cellular model $[19,48]$. This effect was hindered in RPE cells co-cultured with HUVEC treated with either Aflibercept or Ranibizumab. Thus, although not directly examined, the activation of intracellular signaling downstream Akt and ERK1/2 could be hypothesized to be involved in the protective effects elicited by the anti-VEGF agents against AMD. The signaling pathways downstream Akt and ERK1/2 activation are known to be involved in the regulation of cellular proliferation, differentiation, and survival processes in many cell lines, amongst which are RPE cells. In this respect, it is notable that the effects of the two anti-VEGF agents on cell viability and mitochondrial membrane potential were reduced in the presence of PI3K, ERK1/2, and p38MAPK inhibitors. In particular, the modulation of PI3K/Akt pathway could represent a promising therapeutic tool for the prevention of the RPE degeneration, and theoretically, for the treatment of eye disorders, such as AMD $[49,50]$.

\section{Conclusion}

In conclusion, the co-culture experiments would confirm the importance of the cross talk between HUVEC and RPE cells in the prevention of oxidative stress damage and RPE cell apoptosis, and in eliciting the protective effects of Aflibercept and Ranibizumab.

Our results could also indicate that the progression of atrophy in patients with neovascular AMD treated with Ranibizumab or Aflibercept are not due to the treatment itself, but to additional local factors. Specific subtypes of neovascular AMD have shown different natural evolution, thus, with major probability to progress to the atrophy stage. Therefore, further clinical and experimental studies are needed to better understand the interaction between anti-VEGF treatment and the progression of atrophy in patients with AMD.

\section{Acknowledgements}

This research did not receive any specific grant from funding agencies in the public, commercial, or not-for-profit sectors. We thank Azienda Ospedaliero-Universitaria of Novara for its help.

Stefano De Cillà, Elena Grossini: design of the work, interpretation of data for the work; Serena Farruggio, Grazia Cocomazzi, David Mary, Micol Alkabes, Luca Rossetti, Stela Vujosevic: acquisition, analysis, interpretation of data for the work Stefano De Cillà, Serena 


\section{Cellular Physiology Cell Physiol Biochem 2020;54:161-179 \begin{tabular}{ll|l} 
DOl: 10.33594/000000212 202020 The Author(s). Published by & \\
and Biochemistry Publishd & &
\end{tabular}

Farruggio, Grazia Cocomazzi, David Mary, Micol Alkabes, Luca Rossetti, Stela Vujosevic, Elena Grossini: drafting the work and critical revision Stefano De Cillà, Serena Farruggio, Grazia Cocomazzi, David Mary, Micol Alkabes, Luca Rossetti, Stela Vujosevic, Elena Grossini: final approval of the version to be published and agreement to be accountable for all aspects of the work in ensuring that questions related to the accuracy or integrity of any part of the work are appropriately investigated and resolved.

\section{Disclosure Statement}

The authors have no conflicts of interest to declare.

\section{References}

1 Saenz-de-Viteri M, Fernández-Robredo P, Hernández M, Bezunartea J, Reiter N, Recalde S, García-Layana A: Single- and repeated-dose toxicity study of bevacizumab, ranibizumab and aflibercept in ARPE-19 cells under normal and oxidative stress conditions. Biochem Pharmacol 2016;103:129-139.

2 Handa JT: How does the macula protect itself from oxidative stress? Mol Aspects Med 2012;33:418-435.

3 Zając-Pytrus HM, Pilecka A, Turno-Kręcicka A, Adamiec-Mroczek J, Misiuk-Hojło M: The Dry Form of AgeRelated Macular Degeneration (AMD): The Current Concepts of Pathogenesis and Prospects for Treatment. Adv Clin Exp Med 2015;24:1099-1104.

4 Wang L, Clark ME, Crossman DK, Kojima K, Messinger JD, Mobley JA, Curcio CA: Abundant Lipid and Protein Components of Drusen. PLoS One 2010;5:e10329.

5 Totan Y, Koca C, Erdurmuş M, Keskin U, Yiğitoğlu R: Endothelin-1 and Nitric Oxide Levels in Exudative AgeRelated Macular Degeneration. J Ophthalmic Vis Res 2015;10:151-154.

6 Kauppinen A, Paterno JJ, Blasiak J, Salminen A, Kaarniranta K: Inflammation and its role in age-related macular degeneration. Cell Mol Life Sci 2016;73:1765-1786.

7 Bergen AA, Arya S, Koster C Pilgrim MG, Wiatrek-Moumoulidis D, van der Spek PJ, Hauck SM, Boon CJF, Emri E, Stewart AJ, Lengyel I: On the origin of proteins in human drusen: The meet, greet and stick hypothesis. Prog Retin Eye Res 2018;70:55-84.

8 Hernández-Zimbrón LF, Zamora-Alvarado R, Ochoa-De la Paz L, Velez-Montoya R, Zenteno E, GuliasCañizo R, Quiroz-Mercado H, Gonzalez-Salinas R: Age-Related Macular Degeneration: New Paradigms for Treatment and Management of AMD. Oxid Med Cell Longev 2018;2018:8374647.

9 Mitter SK, Song C, Qi X, Mao H, Rao H, Akin D, Lewin A, Grant M, Dunn W Jr, Ding J, Bowes Rickman C, Boulton M: Dysregulated autophagy in the RPE is associated with increased susceptibility to oxidative stress and AMD. Autophagy 2014;10:1989-2005.

10 Bhutto IA, Baba T, Merges C, McLeod DS, Lutty GA: Low nitric oxide synthases (NOSs) in eyes with agerelated macular degeneration (AMD). Exp Eye Res 2010;90:155-167.

11 Totan Y, Cekiç O, Borazan M, Uz E, Sögüt S, Akyol O: Plasma malondialdehyde and nitric oxide levels in age related macular degeneration. Br J Ophthalmol 2001;85:1426-1428.

12 Keles S, Ates O, Kartal B, Alp HH, Ekinci M, Ceylan E, Ondas O, Arpali E, Dogan S, Yildirim K, Keles MS: Evaluation of cardiovascular biomarkers in patients with agerelated wet macular degeneration. Clin Ophthalmol 2014;8:1573-1578.

13 Sripathi SR, He W, Um JY, Moser T, Dehnbostel S, Kindt K, Goldman J, Frost MC, Jahng WJ: Nitric oxide leads to cytoskeletal reorganization in the retinal pigment epithelium under oxidative stress. Adv Biosci Biotechnol 2012;3:1167-1178.

14 Goldstein IM, Ostwald P, Roth S: Nitric oxide: a review of its role in retinal function and disease. Vision Res 1996;36:2979-2994.

15 Ostwald P, Roth S: Nitric oxide leads to cytoskeletal reorganization in the retinal pigment epithelium under oxidative stress. Adv Biosci Biotechnol 2012;3:1167-1178.

16 Friedman E: A hemodynamic model of the pathogenesis of age-related macular degeneration. Am J Ophthalmol 1997;124:677-682. 


\section{Cellular Physiology Cell Physiol Biochem 2020;54:161-179 \begin{tabular}{l|l|l|l|l}
\hline DOI: 10.33594/000000212 & 2020 The Author(s). Published by
\end{tabular} and Biochemistry Published online: 12 February 2020 Cell Physiol Biochem Press GmbH\&Co. KG \\ De Cillà et al.: Anti Vascular Endothelial Growth Factors and Retinal Function}

17 Grunwald JE, Pistilli M, Daniel E, Ying GS, Pan W, Jaffe GJ, Toth CA, Hagstrom SA, Maguire MG, Martin DF: Incidence and Growth of Geographic Atrophy during 5 Years of Comparison of Age-Related Macular Degeneration Treatments Trials. Ophthalmology 2017;124:97-104.

18 Kimoto K, Kubota T: Anti-VEGF Agents for Ocular Angiogenesis and Vascular Permeability. J Ophthalmol 2012;2012:852-883.

19 De Cillà S, Farruggio S, Vujosevic S Raina G, Filippini D, Gatti V, Clemente N, Mary D, Vezzola D, Casini G, Rossetti L, Grossini E: Anti-Vascular Endothelial Growth Factors Protect Retinal Pigment Epithelium Cells Against Oxidation by Modulating Nitric Oxide Release and Autophagy. Cell Physiol Biochem 2017;42:17251738.

20 Surico D, Bordino V, Cantaluppi V Mary D, Gentilli S, Oldani A, Farruggio S, Melluzza C, Raina G, Grossini E: Preeclampsia and intrauterine growth restriction: Role of human umbilical cord mesenchymal stem cellstrophoblast cross-talk. PLoS One 2019;14:e0218437.

21 Savoia P, Raina G, Camillo L Farruggio S, Mary D, Veronese F, Graziola F, Zavattaro E, Tiberio R, Grossini E: Anti-oxidative effects of $17 \beta$-estradiol and genistein in human skin fibroblasts and keratinocytes. J Dermatol Sci 2018;92:62-77.

22 Grossini E, Raina G, Farruggio S, Camillo L, Molinari C, Mary D, Walker GE, Bona G, Vacca G, Moia S, Prodam F, Surico D: Intracoronary Des-Acyl Ghrelin Acutely Increases Cardiac Perfusion Through a Nitric OxideRelated Mechanism in Female Anesthetized Pigs. Endocrinology 2016;157:2403-2415.

23 Grossini E, Gramaglia C, Farruggio S, Bellofatto K, Anchisi C, Mary D, Vacca G, Zeppegno P: Asenapine increases nitric oxide release and protects porcine coronary artery endothelial cells against peroxidation. Vascul Pharmacol 2014;60:127-141.

24 Farruggio S, Raina G, Cocomazzi G, Librasi C, Mary D, Gentilli S, Grossini E: Genistein improves viability, proliferation and mitochondrial function of cardiomyoblasts cultured in physiologic and peroxidative conditions. Int J Mol Med 2019;44:2298-2310.

25 Grossini E, Farruggio S, Raina G, Mary D, Deiro G, Gentilli S: Effects of Genistein on Differentiation and Viability of Human Visceral Adipocytes. Nutrients 2018;10:pii:E978.

26 Chen LJ, Ito S, Kai H, Nagamine K, Nagai N, Nishizawa M, Abe T, Kaji H: Microfluidic co-cultures of retinal pigment epithelial cells and vascular endothelial cells to investigate choroidal angiogenesis. Sci Rep 2017;7:35-38.

27 Spencer C, Abend S, McHugh KJ, Saint-Geniez M: Identification of a synergistic interaction between endothelial cells and retinal pigment epithelium. J Cell Mol Med 2017;10:2542-2552.

28 Alizadeh E, Mammadzada P, André H: The Different Facades of Retinal and Choroidal Endothelial Cells in Response to Hypoxia. Int J Mol Sci 2018;3:pii:E3846.

29 Malik D, Tarek M, Caceres del Carpio J, Ramirez C, Boyer D, Kenney MC, Kuppermann BD: Safety profiles of anti-VEGF drugs: bevacizumab, ranibizumab, aflibercept and zivaflibercept on human retinal pigment epithelium cells in culture. Br J Ophthalmol 2014;98:i11-16.

30 Stuart GJ, Boulton ME: Consequences of oxidative stress in age-related macular degeneration. Mol Aspects Med 2012;33:399-417.

31 Kim MH, Chung J, Yang JW, Chung SM, Kwag NH, Yoo JS: Hydrogen peroxideinduced cell death in a human retinal pigment epithelial cell line, ARPE-19. Korean J Ophthalmol 2003;17:19-28.

32 Kaczara P, Sarna T, Burke JM: Dynamics of H2O2 Availability to ARPE-19 Cultures in Models of Oxidative Stress. Free Radic Biol Med 2010;48:1064-1070.

33 Liang FQ Godley BF: Oxidative stress-induced mitochondrial DNA damage in human retinal pigment epithelial cells: a possible mechanism for RPE aging and age-related macular degeneration. Exp Eye Res 2003;76:397-403.

34 Javadov S, Karmazyn M: Mitochondrial permeability transition pore opening as an endpoint to initiate cell death and as a putative target for cardioprotection. Cell Physiol Biochem 2007;20:1-22.

35 Ormel J, De Jonge P: Unipolar depression and the progression of coronary artery disease: toward an integrative model. Psychother Psychosom 2011;80:264-274.

36 Green DR, Reed JC: Mitochondria and apoptosis. Science 1998;281:1309-1312.

37 Russell JW, Golovoy D, Vincent AM, Mahendru P, Olzmann JA, Mentzer A, Feldman EL: High glucose-induced oxidative stress and mitochondrial dysfunction in neurons. FASEB J 2002;16:1738-1748.

38 Juel HB, Faber C, Svendsen SG, Vallejo AN, Nissen MH: Inflammatory cytokines protect retinal pigment epithelial cells from oxidative stress-induced death. PLoS One 2013:8:e64619. 


\section{Cellular Physiology Cell Physiol Biochem 2020;54:161-179 and Biochemistry Published online: 12 February 2020 ( ) 2020 The Author(s). Published by \\ $\begin{array}{ll}\text { De Cillà et al.: Anti Vascular Endothelial Growth Factors and Retinal Function } & \end{array}$}

39 Malek G, Dwyer M, McDonnell D: Exploring the potential role of the oxidant-activated transcription factor aryl hydrocarbon receptor in the pathogenesis of AMD. Adv Exp Med Biol 2012;723:51-59.

40 Barot M, Gokulgandhi MR, Mitra AK: Mitochondrial Dysfunction in Retinal Diseases. Curr Eye Res 2011;36:1069-1107.

41 Armstrong JS: Mitochondrial membrane permeabilization: the sine qua non for cell death. Bioessays 2006;28:253-260.

42 Gemenetzi M, Lotery AJ, Patel PJ: Risk of geographic atrophy in age-related macular degeneration patients treated with intravitreal anti-VEGF agents. Eye (Lond) 2017;31:1-9.

43 Lois N, McBain V, Abdelkader E, Scott NW, Kumari R: Retinal pigment epithelial atrophy in patients with exudative age-related macular degeneration undergoing anti-vascular endothelial growth factor therapy. Retina 2013;33:13-22.

44 Chakravarthy U, Harding SP, Rogers CA, Downes SM, Lotery AJ, Culliford LA, Reeves BC, IVAN study investigators: Alternative treatments to inhibit VEGF in age-related choroidal neovascularisation: 2-year findings of the IVAN randomised controlled trial. Lancet 2013;382:1258-1267.

45 Bhisitkul RB, Mendes TS, Rofagha S, Enanoria W, Boyer DS, Sadda SR, Zhang K: Macular atrophy progression and 7-year vision outcomes in subjects from the ANCHOR, MARINA, and HORIZON studies: the SEVEN-UP study. Am J Ophthalmol 2015;159:915-924.

46 Wons J, Wirth MA, Graf N, Becker MD, Michels S: Comparison of progression rate of retinal pigment epithelium loss in patients with neovascular age-related macular degeneration treated with Ranibizumab and Aflibercept. J Ophthalmol 2017;2017:7432739.

47 Crabtree MJ, Brixey R, Batchelor $\mathrm{H}$, Hale AB, Channon KM: Integrated redox sensor and effector functions for tetrahydrobiopterin- and glutathionylation-dependent endothelial nitric- oxide synthase uncoupling. J Biol Chem 2013;288:561-569.

48 Baek SM, Yu SY, Son Y, Hong HS: Substance P promotes the recovery of oxidative stress-damaged retinal pigmented epithelial cells by modulating Akt/GSK-3 $\beta$ signaling. Mol Vis 2016;22:1015-1023.

49 Zha X, Wu G, Zhao X, Zhou L, Zhang H, Li J, Ma L, Zhang Y: PRDX6 Protects ARPE-19 Cells from Oxidative Damage via PI3K/AKT Signaling. Cell Physiol Biochem 2015;36:2217-2228.

50 Zheng W, Meng Q, Wang H, Yan F, Little PJ, Deng X, Lin S: IGF-1-Mediated Survival from Induced Death of Human Primary Cultured Retinal Pigment Epithelial Cells Is Mediated by an Akt-Dependent Signaling Pathway. Mol Neurobiol 2018;55:1915-1927. 